\title{
Upaya Meningkatkan Hasil Belajar Matematika Peserta Didik Melalui Model Pembelajaran Discovery Learning di Kelas III SDN 03/X Tanjung Solok Semester Ganjil T.A 2021/2022
}

\author{
Aisyah \\ SDN 03/X Tanjung Solok \\ Jl. Puskesmas RT.007/ RW.002, Tanjung Solok, Kec. Kuala Jambi, Kab. Tanjung Jabung Timur Prov. Jambi \\ aisyah@gmail.com
}

\begin{abstract}
This study aims to describe and obtain information on improving mathematics learning outcomes through the Discovery Learning learning model. This research is classroom action research consisting of two cycles, each cycle consisting of two meetings. Each meeting consists of four stages, namely planning, implementation, observation, and reflection. The subjects of this study were the thirds' grade students of SDN 03/X Tanjung Solok, totaling 13 people. This research was conducted in the odd semester of the 2020/2021 academic year. Data collection techniques using tests, observations, and documentation. Data were analyzed using percentages. The results showed that through the Discovery Learning learning model, the thirds' grade students of SDN 03/X Tanjung Solok could improve their mathematics learning outcomes by giving praise.
\end{abstract}

Keywords: Mathematics Learning Outcomes, Discovery Learning

\begin{abstract}
Abstrak
Penelitian ini bertujuan untuk mendeskripsikan dan mendapatkan informasi peningkatan hasil belajar Matematika melalui model pembelajaran Discovery Learning. Penelitian ini merupakan penelitian tindakan kelas yang terdiri dari dua siklus masing-masing siklus terdiri dari dua kali pertemuan. Masing-masing petemuan terdiri dari empat tahapan yaitu perencanaan, pelaksanaan, observasi dan refleksi. Subjek penelitian ini adalah siswa kelas III SDN 03/X Tanjung Solok yang berjumlah sebanyak 13 orang. Penelitian ini dilaksanakan pada semseter ganjil tahun ajaran 2020/2021. Teknik pengumpulan data menggunakan tes, observasi, dan dokumentasi. Data dianalisis menggunakan persentase. Hasil penelitian menunjukkan bahwa melalui model pembelajaran Discovery Learning dapat meningkatkan hasil belajar Matematika siswa kelas III SDN 03/X Tanjung Solok dengan tindakan pemberian pujian.
\end{abstract}

Kata kunci: Hasil Belajar Matematika, Discovery Learning

Copyright (c) 2022 Aisyah

Corresponding author: Aisyah

Email Address: aisyah@gmail.com (Jl. Puskesmas, Tanjung Solok, Tanjung Jabung Timur, Jambi)

Received 10 January 2022, Accepted 20 January 2022, Published 29 January 2022

\section{PENDAHULUAN}

Proses pembelajaran di sekolah saat ini harus dilakukan perubahan, peserta didik jangan lagi dianggap sebagai botol kosong yang harus diisi air sampai penuh. Hal itu menunjukkan bahwa tidak adanya partisipasi dari peserta didik itu sendiri untuk berusaha mendapatkan ilmu dari guru. Artinya peserta didik hanya duduk diam menerima pelajaran dari guru secara pasif (Hamalik:2011). Pendidikan merupakan salah satu sektor penting dalam pembangunan di setiap negara. Menurut Undang-Undang No. 20 Tahun 2003 tentang Sisdiknas dalam pasal 1 disebutkan bahwa pendidikan merupakan usaha sadar dan terencana untuk mewujudkan suasana belajar dan proses pembelajaran agar peserta didik secara aktif mengembangkan potensi dirinya untuk memiliki kekuatan spiritual keagamaan, pengendalian diri, kepribadian, kecerdasan, akhlak mulia, serta keterampilan yang 
diperlukan dirinya, masyarakat, mengembangkan segala potensi yang dimiliki peserta didik melalui proses pembelajaran.

Dalam pasal 4 dijelaskan bahwa peserta didik adalah anggota masyarakat yang berusaha mengembangkan potensi diri melalui proses pembelajaran yang tersedia pada jalur, jenjang, dan jenis pendidikan tertentu. Keberhasilan program pendidikan melalui pembelajaran di sekolah sebagai lembaga pendidikan formal sangat dipengaruhi oleh beberapa faktor yaitu: peserta didik, kurikulum, tenaga kependidikan, biaya, sarana dan prasarana serta faktor lingkungan. Apabila faktor-faktor tersebut dapat terpenuhi sudah tentu akan memperlancar proses belajar-mengajar, yang akan menunjang pencapaian hasil belajar yang maksimal yang pada akhirnya akan meningkatkan mutu pendidikan (Djahiri, 2003).

Pembelajaran yang baik memungkinkan peserta didik dapat berinteraksi dengan guru dan juga lingkungan, sehingga dalam proses pembelajarannya tidak hanya sekedar menghafal sejumlah fakta atau informasi, akan tetapi pristiwa mental dan proses berpengalaman (Wina Sanjaya:2010). Sesuai dengan peraturan pemerintah No. 32 Tahun 2013 pasal 19 dikatakan bahwa "proses pembelajaran pada satuan pendidikan diselenggarakan secara interaktif, inspiratif, menyenangkan, menantang, memotivasi peserta didik untuk berpatisipasi aktif, serta memberikan ruang yang cukup bagi prakarsa, kreativitas dan kemandirian sesuai dengan bakat, minat dan perkembangan fisik serta psikologis peserta didik".

Menurut Johnson dan Rising dalam bukunya yang dikutip oleh Erman Suherman mengatakan bahwa matematika adalah pola berpikir, pola mengkoordinasikan, pembuktian yang logik, matematika itu adalah bahasa yang menggunakan istilah yang didefinisikan dengan cermat, jelas, dan akurat, presentasinya dengan simbol dan padat, lebih berupa bahasa simbol mengenai ide daripada mengenai bunyi (Erman Suherman (2003:17). Matematika adalah disiplin ilmu yang mempelajari tentang tata cara berpikir dan mengolah logika, baik secara kuantitatif maupun secara kualitatif (Erman Suherman, 2003:298).

Tujuan pembelajaran matematika meliputi dua hal, yaitu mempersiapkan peserta didik agar sanggup menghadapi perubahan keadaan di dalam kehidupan yang selalu berkembang melalui latihan bertindak dengan dasar pemikiran secara logis, rasional, kritis, cermat, jujur, efisien, maupun efektif dan mempersiapkan peserta didik agar dapat menggunakan matematika serta pola pikir matematika dalam kehidupan sehari-hari dan menerapkannya dalam mempelajari ilmu pengetahuan lainnya (Suherman, dkk:2003). Salah satu indikator tercapai atau tidaknya tujuan pembelajaran adalah dengan melihat hasil belajar yang dicapai oleh peserta didik (Djamarah, 2000).

Matematika adalah pelajaran yang kurang diminati peserta didik. Mayoritas peserta didik menolak dan menghindari pelajaran ini, alasannya peserta didik menganggap bahwa matematika adalah pelajaran yang sangat sulit karena banyak menggunakan rumus-rumus yang membingungkan. Hal ini terbukti berdasarkan hasil observasi awal yang peneliti temukan di SDN 03/X Tanjung Solok khusus nya dikelas III pada mata pelajaran Matematika masih banyak yang hasil belajarnya rendah. 
Hal ini dapat dilihat dari nilai ulangan harian peserta didik. masih banyak peserta didik yang hasil belajarnya di bawah KKM (70) dengan rata-rata nilai ulangan harian 55. Untuk menyikapi permasalahan tersebut peneliti mencoba mencari solusinya untuk memperbaiki pembelajaran dengan mengkondisikan pembelajaran yang memudahkan, mengasyikkan, dan menyenangkan bagi peserta didik.

Rendahya tingkat hasil belajar peserta didik di kelas III tersebut dipengaruhi beberapa faktor, salah satunya adalah model pembelajaran yang masih monoton/konvensional. Model pembelajaran yang bertumpu pada guru, sehingga gerak anak menjadi kurang. Model pembelajaran yang seperti ini yang membuat hasil belajar peserta didik menjadi rendah. Oleh karena itu, guru perlu merancang pembelajaran yang dapat meningkatkan pemahaman konsep peserta didik terhadap suatu materi (Suleman, 2013). Salah satu pembelajaran yang mementingkan adanya perolehan konsep adalah model Discovery Learning.

Discovery Learning merupakan salah satu model pembelajaran dimana guru tidak langsung memberikan hasil akhir atau kesimpulan dari materi yang disampaikannya melainkan peserta didik diberi kesempatan mencari dan menemukan hasil data tersebut, sehingga proses pembelajaran ini yang akan diingat oleh peserta didik sepanjang masa dan hasil yang ia dapat tidak mudah dilupakan (Cahyo (2013). Bruner mengatakan bahwa Discovery Learning mengacu pada penguasaan pengetahuan untuk dirinya sendiri dengan cara perumusan dan pengujian hipotesis-hipotesis, bukan sekedar membaca dan mendengarkan penjelasan dari guru melainkan dengan penalaran induktif (Schunk, 2012). tujuan penelitian ini adalah untuk mengungkapkan data, informasi dan membahas tentang upaya meningkatkan hasil belajar matematika melalui model pembelajaran discovery learning di kelas III SDN 03/X Tanjung Solok.

Belajar adalah suatu proses yang kompleks yang terjadi pada diri setiap orang sepanjang hidupnya. Salah satu pertanda bahwa seseorang itu telah belajar adalah adanya perubahan tingkah laku pada diri orang itu yang mungkin disebabkan oleh terjadinya perubahan pada tingkat pengetahuan, keterampilan, atau sikapnya (Azhar Arsyad:2005).

Belajar adalah suatu proses internal yang kompleks yang terlibat dalam proses internal tersebut diantaranya meliputi unsur afektif (berkaitan dengan sikap, nilai-nilai, ketertarikan, apresiasi, dan penyesuaian perasaan sosial) (Dimyati \& Mudjiono :2006). Belajar juga bisa diartikan sebagai semua aktivitas mental atau psikis yang berlangsung dalam interaksi aktif dalam lingkungan, yang menghasilkan perubahan-perubahan dalam pengelolaan pemahaman.

Hasil belajar peserta didik di kelas terkumpul dalam himpunan hasil belajar kelas. Semua hasil belajar tersebut merupakan hasil dari suatu interaksi tindak belajar dan tindak mengajar. Dari sisi guru, tindak mengajar di akhiri dengan proses evaluasi hasil belajar, sedangkan dari sisi peserta didik, hasil belajar merupakan berakhirnya puncak proses belajar (Dimyati dan Mudjiono, 2009: 3). Hasil belajar merupakan tujuan akhir dilaksanakannya kegiatan pembelajaran di sekolah. Hasil belajar dapat ditingkatkan melalui usaha sadar yang dilakukan secara sistematis mengarah kepada perubahan yang 
positif yang kemudian disebut dengan proses belajar. Akhir dari proses belajar adalah perolehan suatu hasil belajar peserta didik. Hasil belajar adalah variable metode dan kondisi pembelajaran, variable hasil pembelajaran juga dapat diklasifikasikan dengan cara yang sama, pada tingkat yang amat umum sekali hasil pembelajaran dapat diklasifikasikan menjadi 3 (tiga) yaitu keefektifan, efesisensi, dan daya tarik (Uno :2011).

Pembelajaran adalah suatu kombinasi yang tersusun, meliputi unsur manusiawi, materiel, fasilitas, perlengkapan, dan prosedur yang saling mempengaruhi untuk mencapai tujuan pembelajaran (Zainal Aqib :2002) Pembelajaran pada hakekatnya adalah proses interaksi antara peserta didik dengan lingkungannya, sehingga terjadi perubahan perilaku ke arah yang lebih baik. Mustafa menyebutkan bahwa matematika adalah ilmu tentang kuantitas, bentuk, susunan, dan ukuran, yang utama adalah metode dan proses untuk menemukan dengan konsep yang tepat dan lambang yang konsisten, sifat dan hubungan antara jumlah dan ukuran, baik secara abstrak, matematika murni atau dalam keterkaitan manfaat pada matematika terapan (dalam Tri Wijayanti :2011). Pembelajaran Matematika tidak lepas dari pengertian pembelajaran dan pengertian ilmu Matematika itu sendiri (E. Mulyasa :2006).

Model pembelajaran digunakan guru sebagai pedoman dalam merencanakan pembelajaran di kelas. Model pembelajaran adalah unsur penting dalam kegiatan belajar mengajar untuk mencapai tujuan pembelajaran. Joyce \& Weil berpendapat bahwa model pembelajaran adalah suatu rencana atau pola yang dapat digunakan untuk membentuk kurikulum (rencana pembelajaran jangka panjang), merancang bahan-bahan pembelajaran, dan membimbing pembelajaran di kelas atau yang lain (dalam Rusman :2012).

Model pembelajaran discovery menuntut guru untuk lebih kreatif menciptakan situasi yang dapat membuat peserta didik belajar aktif menemukan pengetahuan sendiri. Menurut Bruner Model Discovery Learning didefinisikan sebagai proses pembelajaran yang terjadi bila pelajar tidak disajikan dalm bentuk finalnya, tetapi diharapkan mengorganisasi sendiri (dalam Emetembun:1986). Model Discovery Learning adalah cara belajar memahami konsep, arti, dan hubungan melalui proses intuitif untuk akhirnya sampai kepada suatu kesimpulan (Budiningsih :2005).

Pembelajaran discovery melalui kegiatan eksperimen dapat menambah pengetahuan dan keterampilan peserta didik secara stimulan (Sani, 2013: 98). Penemuan adalah terjemahan dari discovery. Menurut Sund, discovery adalah proses mental dimana peserta didik mampu mengasimilasikan sesuatu konsep atau prinsip". Proses mental tersebut ialah mengamati, mencerna, mengerti, mengolong-golongkan, membuat dugaan, menjelaskan, mengukur, membuat kesimpulan dan sebagainya (Roestiyah, 2001:20), sedangkan menurut Bruner, "penemuan adalah suatu proses, suatu jalan/cara dalam mendekati permasalahan bukannya suatu produk atau item pengetahuan tertentu".

Discovery learning adalah cara untuk menemukan oleh diri sendiri, bukan ditemukan oleh orang lain atau sumber lain. Peserta didik diminta untuk mencari tahu atau membayangkan sesuatu. 
Pembelajaran discovery memberi kesempatan bagi peserta didik untuk mengumpulkan, menyusun, memanipulasi, dan menganalisis data karena guru tidak memberi tahu peserta didik secara langsung, tetapi peserta didik menemukan konsep melalui serangkaian data atau informasi yang diperoleh melalui pengamatan atau percobaan. (Aulss and Shore, 2008: 121). Tujuan kedua discovery learning untuk membantu peserta didik mengetahui bagaimana pengetahuan dirumuskan. Tujuan ketiga untuk meningkatkan kemampuan berpikir peserta didik (dalam The Act of Teaching :2006). Creickshank et all menjelaskan tujuan discovery learning agar peserta didik mencari tahu dan menemukan sendiri, peserta didik diharapkan tidak bergantung terlalu banyak dalam menerima pengetahuan dari guru dan menerima kesimpulan dari yang lain.

\section{METODE}

\section{Setting Penelitian}

Jenis penelitian ini adalah penelitian tindakan kelas. Penelitian ini dilaksanakan di SDN 03/X Tanjung Solok pada semester ganjil, tahun ajaran 2021/2022. Subjek dalam penelitian ini adalah siswa III dengan jumlah peserta didik 13 orang. Prosedur penelitian ini meliputi perencanaan, pelaksanaan, pengamatan, dan refleksi. Penelitian ini dilaksanakan dalam dua siklus, masing-masing siklus terdiri dari dua kali pertemuan. Teknik yang digunakan dalam pengumpulan data adalah observasi, tes, catatan lapangan dan dokumentasi. Data dianalisis melalui persentase dan reduksi data.

\section{HASIL DAN DISKUSI}

\section{Siklus I}

\section{Perencanaan}

Perencanaan disusun berdasarkan masalah dan hipotesis tindakan yang diuji secara empirik sehingga perubahan yang diharapkan dapat meningkatkan hasil belajar peserta didik. Sebelum dilaksanakan pembelajaran, langkah yang dilaksanakan adalah merancang RPP yang bercirikan pembelajaran discovery learning, membuat LKS, Membuat kelompok belajar, dan Membuat lembar Observasi.

\section{Pelaksanaan}

Pertemuan pertama siklus I dilaksanakan pada hari Senin tanggal 13 September 2021 di Kelas III SDN 03/X Tanjung Solok. Tema pokok yang dibahas adalah benda di sekitarku dengan KD nya yaitu mendeskripsikan dan menentukan hubungan antar satuan baku untuk panjang, berat, dan waktu yang umumnya digunakan dalam kehidupan sehari-hari. Pada tahap ini terdiri dari tiga tahapan yaitu kegiatan pendahuluan, kegiatan inti, dan kegiatan penutup.

Pada kegiatan pendahuluan ini guru mengkondisikan peserta didik. Kemudian guru melakukan pembukaan dengan salam pembuka dan berdoa untuk memulai pembelajaran. Guru memeriksa kehadiran peserta didik dan menyiapkan fisik dan psikis peserta didik dalam mengawali kegiatan pembelajaran. Mengajukan pertanyaan yang ada keterkaitannya dengan pelajaran yang akan 
dilakukan. Peserta didik menyanyikan lagu Indonesia Raya dan mendengarkan penjelasan guru tentang pentingnya menanamkan rasa nasionalisme. Lalu, guru melakukan stimulus dengan memberi pertanyaan yang dapat meningkatkan semangat dan motivasi tentang belajar di rumah saat pandemi covid-19. Guru memberikan motivasi dengan memberikan gambaran tentang manfaat mempelajari pelajaran yang akan dipelajari serta memberitahukan materi pelajaran yang akan dibahas pada pertemuan saat itu. Guru memberitahukan tentang kompetensi inti, kompetensi dasar, indikator, dan $\mathrm{KKM} / \mathrm{KBM}$ pada pertemuan yang berlangsung dan pembagian kelompok belajar.

Pada kegiatan ini peserta didik diberi kesempatan untuk membaca wacana, peserta didik diminta untuk mengajukan pertanyaan dari wacana tersebut. Peserta didik mengamati satuan panjang yang ada di penggaris dan bagaimana hubungan antar satuan. Peserta didik diberikan kesempatan untuk menemukan hubungan antara satuan $\mathrm{m}$ dan $\mathrm{cm}$. salah satu perwakilan peserta didik dapat maju ke depan kelas untuk membuktikan hubungan antar satuan panjang tersebut. Setelah membuktikan, guru kembali mengulang bahwa satuan panjang tidak hanya $\mathrm{m}$ dan $\mathrm{cm}$, karena ada beragam satuan panjang. Lalu, guru memberikan contoh soal, peserta didik menyelesaikan soal di buku peserta didik. Selesai mengerjakan, kemudian guru mengkoreksi hasilnya.

Pada kegiatan penutup peserta didik membuat rangkuman/simpulan pelajaran tentang pointpoint penting yang muncul dalam kegiatan pembelajaran yang baru dilakukan dan melakukan refleksi terhadap kegiatan yang sudah dilaksanakan dan tidak lupa menganalisis kekurangan serta kelebihan media pembelajaran. Guru memeriksa pekerjaan peserta didik yang selesai langsung diperiksa, mengagendakan pekerjaan rumah, dan menyampaikan rencana pembelajaran pada pertemuan berikutnya. Peserta didik menyanyikan lagu cik-periuk. Kegiatan kelas di akhiri dengan doa bersama.

Pertemuan ke dua siklus I dilaksanakan pada hari Rabu tanggal 15 September 2021 dengan Tema pokok yang dibahas adalah benda di sekitarku dengan KD nya yaitu mendeskripsikan dan menentukan hubungan antar satuan baku untuk panjang, berat, dan waktu yang umumnya digunakan dalam kehidupan sehari-hari. Pada tahap ini terdiri dari tiga tahapan yaitu kegiatan pendahuluan, kegiatan inti, dan kegiatan penutup.

Pada kegiatan pendahuluan guru melakukan pembukaan dengan salam pembuka dan berdoa untuk memulai pembelajaran. Sebelum memulai pelajaran, guru mengajak peserta didik untuk bernyanyi bersama yang ada pada buku peserta didik, guru juga bisa mengajak peserta didik menyanyikan lagu daerah/nasional yang sesuai dengan tema pelajaran. Memeriksa kehadiran peserta didik. Menyiapkan fisik dan psikis peserta didik dalam mengawali kegiatan pembelajaran. Pada tahap Apersepsi guru Mengaitkan materi/tema/kegiatan pembelajaran yang akan dilakukan dengan pengalaman peserta didik dengan materi/tema/kegiatan sebelumnya. Mengingatkan kembali materi prasyarat dengan bertanya. Mengajukan pertanyaan yang ada keterkaitannya dengan pelajaran yang akan dilakukan.

Pada kegiatan inti peserta didik diberi kesempatan untuk membaca wacana, peserta didik diminta untuk mengajukan pertanyaan dari wacana tersebut. Peserta didik mengamati satuan panjang 
yang ada di penggaris dan bagaimana hubungan antar satuan. Peserta didik diberikan kesempatan untuk menemukan hubungan antara satuan $\mathrm{m}$ dan $\mathrm{cm}$. salah satu perwakilan peserta didik dapat maju ke depan kelas untuk membuktikan hubungan antar satuan panjang tersebut. Setelah membuktikan, guru kembali mengulang bahwa satuan panjang tidak hanya $\mathrm{m}$ dan $\mathrm{cm}$, karena ada beragam satuan panjang. Lalu, guru memberikan contoh soal, peserta didik menyelesaikan soal di buku peserta didik. Selesai mengerjakan, kemudian guru mengkoreksi hasilnya.

Pada kegiatan penutup pertemuan dua siklus I ini peserta didik membuat rangkuman/simpulan pelajaran. tentang point-point penting yang muncul dalam kegiatan pembelajaran yang baru dilakukan dan melakukan refleksi terhadap kegiatan yang sudah dilaksanakan. Guru memeriksa pekerjaan peserta didik yang selesai langsung diperiksa, mengagendakan pekerjaan rumah, dan menyampaikan rencana pembelajaran pada pertemuan berikutnya.

\section{Observasi}

Setelah dilaksanakan proses pembelajaran dengan menggunakan model pembelajaran discovery learning selama dua kali pertemuan, dan setelah akhir pertemuan diadakan tes untuk melihat peningkatan yang terjadi pada siklus I. Berikut dapat dilihat hasil belajar Matematika peserta didik kelas III SDN 03/X Tanjung Solok pada tabel di bawah ini:

Tabel 1. Hasil tes formatif siklus I

\begin{tabular}{|c|c|c|}
\hline No & Uraian & Hasil \\
\hline 1 & Jumlah Nilai & 941 \\
\hline 2 & Rata-rata Nilai & 72.38 \\
\hline 3 & Peserta didik Tuntas & 7 \\
\hline 4 & Peserta didik Tidak Tuntas & 6 \\
\hline 5 & Persentase Peserta didik Tuntas & $54 \%$ \\
\hline 6 & Persentase Peserta didik Tidak Tuntas & $46 \%$ \\
\hline
\end{tabular}

Berdasarkan tabel di atas dapat dismpulkan bahwa rata-rata tes formatif peserta didik sebesar 72,38, sedangkan persentase ketuntasan peserta didik sebesar 54\% dengan 7 peserta didik yang mendapat nilai di atas KKM dan 6 peserta didik dengan nilai dibawah KKM, namun hal ini belum mencapai target yang diiginkan.

4. Refleksi

Pada tahap refleksi ini peneliti dan kolaborator yang bernama Aida Susana, S.Pd.SD. melakukan refleksi pada hari senin tanggal 20 September 2021 yang dilaksanakan diruang majelis guru SDN 03/X Tanjung Solok. Berdasarkan hasil refleksi pada siklus I masih terdapat beberapa kelemahan selama proses pembelajaran, yaitu: 1) Pada aspek pengorganisasian materi ajar, cakupan materi ajar belum luas dikarenakan masih tahap perkenalan dengan model yang baru yaitu discovery learning 2) Pada pelaksanaan guru belum menuliskan topik yang akan dipelajari di papan tulis dan tujuan pembelajaran sulit dimengerti, 3) Peserta didik masih belum berani untuk mengemukakan 
pendapatnya selama diskusi dan di dalam kelompoknya, 4) Dalam kelompok peserta didik masih ada yang dominan aktif dalam kelompok dan ada peserta didik yang pasif di dalam kelompok, 5) Peserta didik masih banyak yang bermain-main selama proses pembelajaran berlangsung

Berdasarkan analisis data tersebut pada refleksi siklus I di atas maka penelitian ini dilanjutkan ke siklus berikutnya dan perlu diadakan perbaikan untuk siklus II. Alasan perlu perbaikan karena belum tercapainya target hasil belajar kelas III SDN 03/X Tanjung Solok dan sasaran penelitian setiap indikator pembelajaran belum tercapai. Maka perbaikan yang akan dilaksanakan pada siklus II antara lain guru harus lebih menguasai langkah-langkah model discovery learning. Guru lebih memotivasi peserta didik untuk aktif dalam mengajukan pertanyaan, menjawab pertanyaan, menyatakan pendapat dan mengemukakan ide serta menanggapi pendapat temannya. Guru mengambil tindakan pemberian hadiah guna memicu semangat peserta didik untuk aktif di dalam kelompok dan merangsang perhatian anak terhadap materi. Memberikan pujian kepada peserta didik yang aktif mengemukakan pendapat.

\section{Siklus II}

a. Perencanaan

Pada tahap perencanaan ini guru mempersiapkan hal-hal sebagai berikut yaitu menyiapkan silabus, Menyiapkan RPP, Menyiapkan sarana dan prasarana untuk belajar, Menentukan KI dan KD, Menentukan indikator pembelajaran, Menentukan instrumen masalah.

b. Pelaksanaan

Pertemuan pertama siklus II dilaksanakan pada hari Senin tanggal 4 oktober 2021. Tema pokok yang dibahas adalah benda di sekitarku. Kompetensi dasar yang diharapkan adalah peserta didik dapat menyelesaikan maslaah yang berkaitan dengan hubungan antar satuan baku panjang, berat, dan waktu yang umumnya digunakan dalam kehidupan sehari-hari. Pada tahap ini terdiri dari tiga tahapan yaitu kegiatan pendahuluan, kegiatan inti, dan kegiatan penutup.

Pada kegiatan pendahuluan guru melakukan pembukaan dengan salam pembuka dan berdoa untuk memulai pembelajaran. Sebelum memulai pelajaran, guru mengajak peserta didik untuk bernyanyi bersama yang ada pada buku peserta didik, guru juga bisa mengajak peserta didik menyanyikan lagu daerah/nasional yang sesuai dengan tema pelajaran. Memeriksa kehadiran peserta didik. Menyiapkan fisik dan psikis peserta didik dalam mengawali kegiatan pembelajaran.

Pada kegiatan inti guru lebih memperbaiki cara belajar dan menggunakan model discovery learning agar kelemahan-kelemahan di siklus I tidak terulang lagi. Peserta didik diberi kesempatan untuk membaca wacana, peserta didik diminta untuk mengajukan pertanyaan dari wacana tersebut. Peserta didik mengamati satuan panjang yang ada di penggaris dan bagaimana hubungan antar satuan. Peserta didik diberikan kesempatan untuk menemukan hubungan antara satuan $\mathrm{m}$ dan $\mathrm{cm}$. salah satu perwakilan peserta didik dapat maju ke depan kelas untuk membuktikan hubungan antar satuan panjang tersebut. Peserta didik yang berani maju ke depan kelas diberi pujan oleh guru. Setelah membuktikan, guru kembali mengulang bahwa satuan panjang tidak hanya $\mathrm{m}$ dan $\mathrm{cm}$, karena ada 
beragam satuan panjang.

Akhir kegiatan Peserta didik membuat rangkuman/simpulan pelajaran tentang poin-poin penting yang muncul dalam kegiatan pembelajaran yang baru dilakukan. Melakukan refleksi terhadap kegiatan yang sudah dilaksanakan. Guru memeriksa pekerjaan peserta didik yang selesai langsung diperiksa. Peserta didik yang selesai mengerjakan projek dengan benar diberi paraf serta diberi nomor urut peringkat, untuk penilaian projek. Memberikan penghargaan kepada kelompok yang memiliki kinerja dan kerjasama yang baik. Mengagendakan pekerjaan rumah. Menyampaikan rencana pembelajaran pada pertemuan berikutnya.

Pertemuan kedua siklus II dilaksanakan pada hari Rabu tanggal 6 Oktober 2021. Tema pokok yang dibahas adalah benda di sekitarku. Kompetensi dasar yang diharapkan adalah peserta didik dapat menyelesaikan maslaah yang berkaitan dengan hubungan antar satuan baku panjang, berat, dan waktu yang umumnya digunakan dalam kehidupan sehari-hari. Pada tahap ini terdiri dari tiga tahapan yaitu kegiatan pendahuluan, kegiatan inti, dan kegiatan penutup.

Pada kegiatan pendahukuan guru melakukan pembukaan dengan salam pembuka dan berdoa untuk memulai pembelajaran. Sebelum memulai pelajaran, guru mengajak peserta didik untuk bernyanyi bersama yang ada pada buku peserta didik, guru juga bisa mengajak peserta didik menyanyikan lagu daerah/nasional yang sesuai dengan tema pelajaran. Memeriksa kehadiran peserta didik. Menyiapkan fisik dan psikis peserta didik dalam mengawali kegiatan pembelajaran. Pada tahap Apersepsi guru Mengaitkan materi/tema/kegiatan pembelajaran yang akan dilakukan dengan pengalaman peserta didik dengan materi/tema/kegiatan sebelumnya. Kemudian mengingatkan kembali materi prasyarat dengan bertanya. Mengajukan pertanyaan yang ada keterkaitannya dengan pelajaran yang akan dilakukan. Guru Memotivasi dengan memberikan gambaran tentang manfaat mempelajari pelajaran yang akan dipelajari.

Sama halnya dengan pertemuan pertama siklus II pada kegiatan inti pertemuan kedua ini peserta didik diberi kesempatan untuk membaca wacana dan guru menginstruksikan untuk membaca dengan serius, peserta didik diminta untuk mengajukan pertanyaan dari wacana tersebut. Kemudian peserta didik mengamati satuan panjang yang ada di penggaris dan bagaimana hubungan antar satuan. Peserta didik diberikan kesempatan untuk menemukan hubungan antara satuan $\mathrm{m}$ dan $\mathrm{cm}$. Kemudian guru mengaitkan pelajaran dengan kehidupan sehari-hari. Salah satu perwakilan peserta didik dapat maju ke depan kelas untuk membuktikan hubungan antar satuan panjang tersebut. Guru memberikan pujian kepada peserta didik yang berani maju dan menjawab pertanyaan. Setelah membuktikan, guru kembali mengulang bahwa satuan panjang tidak hanya $\mathrm{m}$ dan $\mathrm{cm}$, karena ada beragam satuan panjang. Lalu, guru memberikan contoh soal, peserta didik menyelesaikan soal di buku peserta didik. Selesai mengerjakan, kemudian guru mengkoreksi hasilnya. Setelah selesai proses belajar mengajar pada hari itu lalu diadakan tes formatif atau ulangan harian.

Akhir kegiatan peserta didik membuat rangkuman/simpulan pelajaran tentang poin-poin penting yang muncul dalam kegiatan pembelajaran yang baru dilakukan. Melakukan refleksi terhadap 
kegiatan yang sudah dilaksanakan. Guru meutup pelajaran dengan berdo'a yang dipimpin oleh salah satu peserta didik.

c. Observasi

Pada akhir proses belajar mengajar peserta didik diberi tes formatif II dengan tujuan untuk mengetahui tingkat keberhasilan peserta didik dalam proses belajar mengajar yang telah dilakukan. Adapun data hasil penelitian pada siklus II adalah sebagai berikut:

Tabel 2. Hasil tes formatif siklus II

\begin{tabular}{|c|c|c|}
\hline No & Uraian & Hasil \\
\hline 1 & Jumlah Nilai & 951 \\
\hline 2 & Rata-rata Nilai & 73.15 \\
\hline 3 & Peserta didik Tuntas & 12 \\
\hline 4 & Peserta didik Tidak Tuntas & 1 \\
\hline 5 & Persentase Peserta didik Tuntas & 92 \\
\hline 6 & Persentase Peserta didik Tidak Tuntas & 8 \\
\hline
\end{tabular}

Dari tabel di atas diperoleh nilai rata-rata hasil belajar peserta didik adalah 73,15 nilai ini sudah di atas KKM yang ditetapkan yaitu 70 dan persentase ketuntasan belajar mencapai $92 \%$ atau ada 12 peserta didik dari 13 peserta didik yang sudah tuntas belajar. Hasil ini menunjukkan bahwa pada siklus II ini ketuntasan belajar secara klasikal telah mengalami peningkatan lebih baik dari siklus I.

d. Refleksi

Tahap refleksi siklus II dilaksanakan pada hari Senin 11 Oktober 2021 dengan dibantu oleh seorang observer yang bernama Aida Susana, S.Pd., SD. yang bertempat di ruangan majelis guru SDN 03/X Tanjung Solok. Dalam diskusi ini guru dan observer menjelaskan bahwa adanya peningkatan hasil belajar peserta didik ini karena setelah guru menginformasikan bahwa setiap akhir pelajaran akan selalu diberikan hadiah bagi individu maupun kelompok yang aktif dan terbaik sehingga pada pertemuan berikutnya peserta didik lebih termotivasi untuk belajar. Selain itu peserta didik juga sudah mulai mengerti apa yang dimaksudkan dan dinginkan guru dengan menerapkan model pembelajaran discovery learning.

Kelemahan-kelemahan yang terjadi pada siklus I sudah tidak terjadi lagi pada siklus II, hal ini mengakibatkan naiknya persentase ketuntasan peserta didik dan dengan adanya tindakan pemberian hadiah juga memberikan dampak yang sangat baik terhadap hasil belajar peserta didik. Untuk itu penelitian tindakan kelas di kelas III SDN 03/X Tanjung Solok menggunakan model discovery learning ini tidak dilanjutkan pada siklus berikutnya karena persentase ketuntasan yang diharapkan sudah mencapai target yaitu di atas $80 \%$ dan rata-rata klasikal ketuntasan anak sudah di atas KKM yang ditetapkan yaitu 70 .

\section{Diskusi}

Pada pembelajaran dengan model pembelajaran discovery learning ini peserta didik diarahkan 
menemukan konsep dengan bantuan membaca buku melalui kegiatan-kegiatan diskusi secara berkelompok. Dalam pembelajaran, guru membimbing peserta didik berada disamping mereka yang membutuhkan bimbingan, membuat peserta didik merasa puas dan senang dan merasa diperhatikan sehingga peserta didik merasa bersemangat belajar.

Hosnan (2014: 7) menyatakan bahwa belajar pada hakikatnya adalah proses interaksi terhadap semua yang ada di sekitar individu. Hal ini sesuai dengan pendapat Sudjana (2004) bahwa hasil belajar peserta didik pada hakikatnya adalah perubahan tingkah laku sebagai hasil belajar dalam pengertian yang lebih luas mencakup bidang kognitif, afektif, dan psikomotorik. Melaksanakan pengelolaan kelas dengan baik dengan mengubah susunan angota kelompok serta memberikan pujian kepada peserta didik agar peserta didik termotivasi dalam pembelajaran dan dapat meningkatkan hasil belajar Matematika peserta didik kelas III SDN 03/X Tanjung Solok.

Pelaksanaan model discovery learning di kelas III SDN 03/X Tanjung Solok telah memberikan dampak yang positif terhadap hasil belajar peserta didik. Perbandingan perentase ketuntasan pada siklus I dan II adalah sebesar 54\% dan 92\% dengan nilai rata-rata di siklus I yaitu 72,38 dan siklus II yaitu 73,15 Penggunaan model pembelajaran discovery learning membantu meningkatkan kemampuan kognitif peserta didik karena peserta menemukan sendiri pengetahuan dengan bantuan instruksi guru. Proses ini akan membuat pengetahuan yang diperoleh peserta didik sulit dilupakan, seperti yang dijelaskan Roestiyah (2008:21) mengenai kelebihan dan kekurangan metode discovery learning. Keunggulan discovery learning yaitu 1) membantu peserta didik mengembangkan; mempersiapkan, menguasai keterampilan dalam proses kognitif, 2) Peserta didik memperoleh pengalaman/pengetahuan bersifat individual sehingga sulit dilupakan, 3) Dapat membangkitkan semangat belajar peserta didik, 4) Memberi kesempatan kepada peserta didik untuk berkembang maju sesuai kemampuan masing-masing, 5) Mengarahkan cara belajara peserta didik, 6) Membantu menaikkan rasa percaya diri peserta didik, 7) Strategi berpusat pada peserta didik bukan pada guru.

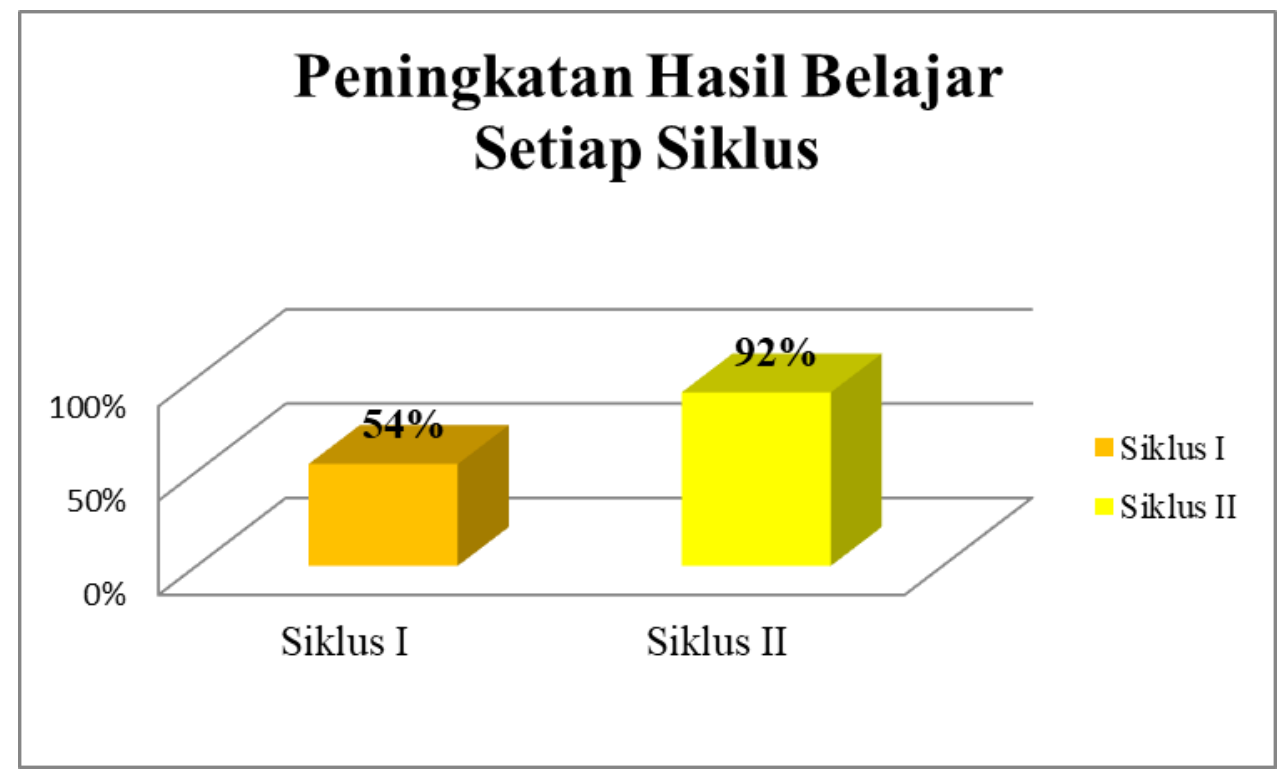

Gambar 1. Ketuntasan Hasil Belajar Per Siklus 


\section{KESIMPULAN}

Dari hasil kegiatan pembelajaran yang telah dilakukan selama dua siklus, dan berdasarkan seluruh pembahasan serta analisis yang telah dilakukan dapat disimpulkan pembelajaran dengan model pembelajaran discovery learning dapat meningkatkan hasil belajar peserta didik yang ditandai dengan peningkatan ketuntasan belajar peserta didik dalam setiap siklus, yaitu Siklus 1 (54\%) dan siklus 2 (92\%). Penerapan model pembelajaran discovery learning melalui tindakan pemberian pujian dapat meningkatkan hasil belajar peserta didik yang ditunjukan dengan peningkatan ketuntasan belajar peserta didik dalam setiap siklus dan peningkatan rata-rata ketuntasan.

Dari hasil penelitian yang diperoleh dari uraian sebelumnya agar proses belajar pembelajaran Matematika lebih efektif dan lebih memberikan hasil yang optimal bagi peserta didik, maka disampaikan saran yaitu untuk melaksanakan model pembelajaran discovery learning memerlukan persiapan yang cukup matang, sehingga peserta didik harus benar-benar siap dan sanggup menerapkan model pembelajaran discovery learning dalam proses belajar mengajar sehingga diperoleh hasil yang optimal. Dalam rangka meningkatkan hasil belajar peserta didik, guru hendaknya lebih aktif dalam mengelola suasana di dalam kelas.

\section{UCAPAN TERIMA KASIH}

Ucapan terima kasih sangat layak disampaikan untuk semua pihak yang telah membantu dalam pengerjaan artikel ini. Baik teman, dosen, kakak, dan yang lainnya. Artikel ini dapat dibuat karena adanya bantuan mereka. Semoga artikel ini dapat bermanfaaat untuk banyak pihak.

\section{REFERENSI}

Abdullah, Sani. 2013. Inovasi Pembelajaran. Jakarta: Bumi Aksara.

Abdullah, Sani Ridwan. 2014. Pembelajaran saintifik untuk kurikulum 2013. Jakarta: Bumi Aksara.

Agus, Cahyo. (2013). Panduan Aplikasi Teori Belajar. Jakarta. PT. Diva Press.

Arsyad, Azhar. 2005. Media Pembelajaran. PT RajaGrafindo Persada. Jakarta. Buku Ajar Kelas IV. 2004. Tim Abdi Guru Erlangga.

Aqib, Zainal. 2002. Profesionalisme Guru dalam Pembelajaran. Surabaya: Insan Cendikia.

Budiningsih. (2005)., Discovery Learning Sebagai Pemecahan Masalah Pendidikan Indonesia. Bandung: Bineka Cipta Utama

BSNP. 2006. Permendiknas RI No. 22 Tahun 2006 tentang Standar Isi untuk Satuan Pendidikan Dasar dan Menengah. Jakarta.

Cruickshank, D. R., Jenkins, D. B. \& Metcalf, K. K. (2006). The act of teaching (4th ed.). New York: McGraw-Hill Companies. Inc

Djamarah, Syaiful Bahri. 2000. Guru dan Anak Didik dalam Interaksi Edukatif. Jakarta: Rineka Cipta. Dimyati dan Mudjiono. 2006. Belajar dan Pembelajaran. Jakarta: PT Rineke Cipta

E. Mulyasa. 2006. Kurikulum yang di sempurnakan. Bandung: PT Remaja Rosdakarya. 
Emetembun. (1986). Penemuan Sebagai Discovery Learning Dalam Belajar. Yogyakarta: Media Ray

Hamalik, Oemar. 2011. Kurikulum dan Pembelajaran. Jakarta: Bumi Aksara.

Hamzah B. Uno. (2011). Teori Motivasi dan Pengukurannya: Analisis di Bidang Pendidikan. Jakarta: Bumi aksara

Hosnan. 2014. Pendekatan Saintifik dan Kontekstual dalam Pembelajaran Abad 21. Bogor: Ghalia Indonesia.

Mustafa, Wijayanti Tri (2011). PengertianMatematika. Jakarta: PT Gramedia

Nasution, 2006, Berbagai Pendekatan Dalam Proses Belajar Mengajar (Jakarta: Bumi

Aksara)

Roestiyah. 2008. Strategi Belajar Mengajar. Jakarta: Rineka Cipta

Rusman, 2012. Model-model Pembelajaran: Mengembangkan Profesionalisme Guru, Raja Grafindo Persada, Jakarta

Sanjaya, Wina. (2010). Strategi Pembelajaran Berorientasi Standar Proses Pendidikan. Jakarta: Prenada Media Group

Sudjana, Nana. 2004. Dasar-dasar Proses Belajar Mengajar. Bandung: Sinar Baru Algensido Offset

Suherman, Erman dkk. 2003. Strategi Pembelajaran Matematika Kontemporer. Bandung: PT Remaja Rosdakarya

UU Sisdiknas No. 20 Tahun 2003 Pasal 1 Ayat 1. 